\title{
Isolation, Characterization, and Medicinal Potential of Polysaccharides of Morchella esculenta
}

\author{
Syed Lal Badshah ${ }^{1, *(D)}$, Anila Riaz ${ }^{1}$, Akhtar Muhammad ${ }^{1}$, Gülsen Tel Çayan ${ }^{2}$, Fatih Çayan ${ }^{2}$, \\ Mehmet Emin Duru ${ }^{2}$, Nasir Ahmad ${ }^{1}$, Abdul-Hamid Emwas ${ }^{3}$ (D) and Mariusz Jaremko ${ }^{4, *}$ \\ 1 Department of Chemistry, Islamia College University Peshawar, Peshawar 25120, Pakistan; \\ riaz94awan@hotmail.com (A.R.); drakhtarmuhammad@icp.edu.pk (A.M.); nasirshah121@yahoo.com (N.A.) \\ 2 Department of Chemistry and Chemical Processing Technologies, Muğla Vocational School, Muğla Sıtk1 \\ Koçman University, 48000 Muğla, Turkey; gulsen_tel@hotmail.com (G.T.Ç.); fatihcayan@mu.edu.tr (F.Ç.); \\ eminduru@mu.edu.tr (M.E.D.) \\ 3 Core Labs, King Abdullah University of Science and Technology (KAUST), Thuwal 23955-6900, Saudi Arabia; \\ abdelhamid.emwas@kaust.edu.sa \\ 4 Division of Biological and Environmental Sciences and Engineering (BESE), King Abdullah University of \\ Science and Technology (KAUST), Thuwal 23955-6900, Saudi Arabia \\ * Correspondence: shahbiochemist@gmail.com (S.L.B.); mariusz.jaremko@kaust.edu.sa (M.J.)
}

check for updates

Citation: Badshah, S.L.; Riaz, A.; Muhammad, A.; Tel Çayan, G.;

Çayan, F.; Emin Duru, M.; Ahmad, N.; Emwas, A.-H.; Jaremko, M. Isolation, Characterization, and Medicinal Potential of Polysaccharides of Morchella esculenta. Molecules 2021, 26, 1459. https://doi.org/10.3390/ molecules26051459

Academic Editors:

Krystian Marszałek, Shuyi Li,

Ireneusz Kapusta and Jose

Manuel Lorenzo

Received: 30 January 2021

Accepted: 4 March 2021

Published: 8 March 2021

Publisher's Note: MDPI stays neutral with regard to jurisdictional claims in published maps and institutional affiliations.

Copyright: (c) 2021 by the authors. Licensee MDPI, Basel, Switzerland. This article is an open access article distributed under the terms and conditions of the Creative Commons Attribution (CC BY) license (https:/ / creativecommons.org/licenses/by/ $4.0 /)$.

\begin{abstract}
Mushroom polysaccharides are active medicinal compounds that possess immune-modulatory and anticancer properties. Currently, the mushroom polysaccharides krestin, lentinan, and polysaccharopeptides are used as anticancer drugs. They are an unexplored source of natural products with huge potential in both the medicinal and nutraceutical industries. The northern parts of Pakistan have a rich biodiversity of mushrooms that grow during different seasons of the year. Here we selected an edible Morchella esculenta (true morels) of the Ascomycota group for polysaccharide isolation and characterization. Polysaccharopeptides and polysaccharides from this mushroom were isolated using the green chemistry, hot water treatment method. Fourier transform infrared spectroscopy revealed the sugar nature and possible beta-glucan type structure of these polysaccharides. Antioxidant assays showed that the deproteinized polysaccharides have moderate free radical scavenging activity. These isolated polysaccharides exhibited good acetylcholinesterase (AChE) and butyryl cholinesterase (BChE) inhibition activities. Therefore, these polysaccharides may be valuable for the treatment of Alzheimer's and Parkinson's diseases. Further bioassays are needed to discover the true potential of M. esculenta polysaccharides for medicinal purposes.
\end{abstract}

Keywords: Morchella esculenta; polysaccharopeptides; anticholinesterase activity; antioxidant; tyrosinase inhibition

\section{Introduction}

Since prehistoric times, and across different civilizations, mushrooms have been utilized as a dietary source and in medication [1]. Mushrooms possess bioactive constituents that are antioxidant, anti-inflammatory, immunomodulatory, and antidiabetic [2-5]. There are several mushrooms whose polysaccharides have been well characterized by biophysical and biochemical techniques, and their bioactivities show promise for different diseases $[4,5]$. Among these, Ganoderma, Trametes or Coriolus (commonly known as Turkey tail), Lentinus, Morchella, and several other genera have displayed both nutritional and medicinal properties [6]. The Pleurotus mushroom genus is one of the cultivated types, and are generally called oyster or tree mushrooms [7]. The polysaccharides and proteins of Pleurotus possess anticancer and antiviral properties [7]. Immunomodulation and anticancer activity are some of the unique properties that the mushroom polysaccharides are known for, which has caused an increase in their consumption as food over the past few decades [8-10]. Mushroom polysaccharides contain various types of glycosidic bonds and are thus grouped as 
beta-glucans, alpha-glucans, and heteroglycans [9]. Some of them interact with proteins to form polysaccharopeptides [9]. So far, three important clinically well-established antitumor polysaccharides, including lentinan and protein-containing polysaccharides like krestin, have been isolated from Lentinus species, Schizophyllum, and Turkey tails [9,11,12]. These mushrooms have quite large commercial markets in East Asian countries $[9,11,12]$. Chemical analyses of lentinan and schizophyllan showed that they are complete $\beta$-glucans, while the polysaccharide Krestin (PSK) is a protein-bound beta-glucan [9,11,12]. A polysaccharopeptide obtained from a strain of the Coriolus species in China also had anticancer and immune-boosting properties [9]. In Japan, for cancer treatment, a few grams of PSK is given orally to patients during chemotherapy [4]. Different biological test results of PSK showed improvement of immune functions, antiviral defense, body regulation of cholesterol, and prebiotic activity [4,13]. Although the exact mode of action of these mushroom polysaccharides has not yet been established, using them as additional adjuvants with cancer drugs may be of value in cancer treatment. The Agaricus bisporus $\beta$-glucans interact with intestinal cells and activate the immune system and enterocytes [14]. Several other species of Agaricus mushroom have been noted to contain antioxidants and have anticancer properties [15]. Because of these beneficial roles of the mushroom polysaccharides, they have become an interesting area of study in medicinal chemistry. Here, we selected Morchella esculenta mushrooms for polysaccharide isolation and purification, which were then tested for specific bioactivities.

The Morchella genus is one of the most favored mushrooms, and as such, it is highly priced [16]. The Morchella esculenta contains all the important nutrients, from carbohydrates, proteins, polyunsaturated fatty acids, secondary metabolites like phenolic compounds, etc. [17]. The methanolic extract from the mushrooms has potent antioxidant properties and antibacterial activities against different bacteria [17]. It has been observed that the utilization of Morchella esculenta polysaccharides as a food in mice increased the useful gut microbiota as well as the short-chain fatty acids in the body [18]. A $43.6 \mathrm{kDa}$ purified polysaccharide from M. esculenta was shown to contain glucose, mannose, galactose, and arabinose as the monomer units [19]. An $81 \mathrm{kDa}$ M. esculenta polysaccharide was shown to have the potential to cease the growth and spread of human colon cancer in HT29 cells, and its potency is dose and time dependent [2]. Several sterols and fatty acids recognized in the methanolic extract of M. esculenta fruiting bodies had antitumor activity when tested against different human lung cancer cell lines with $\mathrm{IC}_{50}$ values in the range of 157 to $278 \mu \mathrm{M}$ [20]. A polysaccharide isolated from the mycelium of M. esculenta showed antiproliferative activity against hepatoma cell lines [21]. A heteropolysaccharide isolated from M. esculenta had anti-melanogenesis properties [22]. These properties were investigated both in vitro (B16F10 melanoma cells) and in vivo (zebrafish larvae), showing a reduction of melanin production without any cytotoxicity [22]. Thus, $M$. esculenta polysaccharides can be used in skin cancer treatment. The galactomannan polysaccharide isolated from Morchella esculenta enhances the immune response to different diseases [16] and modulates the immune system [23]. It has been reported that polysaccharides from Morchella conica can help treat hepatocarcinomas by reducing the generation of free radicals [21]. It has also been demonstrated that polysaccharides from Morchella conica can potentially modulate the immune system by inhibiting nitric oxide production in lipopolysaccharide-treated macrophages; thus, these polysaccharides could be used for treating inflammatory diseases [24]. The partial chemical modification of polysaccharides from Morchella angusticepes Peck, by adding a carboxymethyl group at C6 in its sugars, resulted in a reduction in cholesterol levels in rats [25]. Thus, these polysaccharides can potentially be used to lower blood and liver cholesterol levels and may be valuable for treating heart coronary diseases. The aim of this scientific work was to determine the free radical scavenging and anticholinesterase and tyrosinase properties of wild-grown M. esculenta polysaccharides in proteinized and deproteinized forms. 


\section{Materials and Methods}

\subsection{Mushroom Collection and Preliminary Treatment}

Morchella esculenta mushrooms were collected from the natural habitat of the khyber Pakhtunkhwa region of Pakistan. A mycological survey was performed by a local expert from the botany department of our university, and a mushroom sample was deposited in their herbarium. The mushrooms were washed with distilled water to remove soil debris, then shade dried and crushed through a grinder. Volatile and non-volatile organic pigments and compounds were removed by dipping the samples in methanol for two weeks, and the process was repeated three times [26,27]. The samples were then filtered and the residue left on the filter paper was further used for polysaccharide extraction [26,27].

\subsection{Polysaccharide Extraction}

The residue left on the filter paper was dried at room temperature. The polysaccharides were extracted by hot water extraction in which the sample was heated in distilled water at $80^{\circ} \mathrm{C}$ for $1-2 \mathrm{~h}[26,27]$. To remove any particulate matter from the solution, it was filtered three times. Then, ethanol was added to the filtrate in a 1:3 ratio. The obtained solution was centrifuged at $3000 \times g$ for $25 \mathrm{~min}[26,27]$. After centrifugation, the upper layer of supernatant was discarded, while the pellet of proteinated polysaccharides was separated, washed with ethanol three times, dried, and stored at $0{ }^{\circ} \mathrm{C}$ in the freezer $[26,27]$.

\subsection{Deproteinization of Polysaccharides}

Deionized water was added to the proteinized polysaccharides, and the $\mathrm{pH}$ of this solution was brought to $\mathrm{pH} 3.0$ using $0.1 \mathrm{M}$ of $\mathrm{HCl}$ solution [26,27]. The diluted and proteinized sample was left at room temperature for 1 day [26,27]. After this, it was centrifuged, and this time the supernatant was isolated in a china dish and oven dried [26,27]. The layer of polysaccharides collected were labelled as the deproteinized polysaccharides [26,27].

\subsection{Fourier Transform Infrared Spectroscopy}

The Fourier transform infrared spectroscopy (FTIR) spectra of polysaccharides were collected using the Tensor II Bruker Germany FTIR spectrometer using the attenuated total reflection (ATR) sampling method. This spectrophotometer was equipped with a global source, a KBr beam and a deuterated triglycine sulphate detector. Spectra were collected from 400 to $4000 \mathrm{~cm}^{-1}$. Approximately $0.5 \mathrm{mg}$ of the sample was used for each test.

\subsection{Antioxidant Bioassays}

\subsubsection{2,2-diphenyl-1-picrylhydrazyl (DPPH) Assay}

The first free radical scavenging activity was performed with 2,2-diphenyl-1-picrylhydrazyl (DPPH) reagent [28]. The reaction mechanism contained the absorption spectrum of free radical-generated changes when they were reduced by an antioxidant compound, and was recorded at $517 \mathrm{~nm}$, where DPPH had maximum absorption [28,29]. Approximately $40.0 \mu \mathrm{L}$ of sample solutions of different concentrations of polysaccharides were taken, and to these solutions, $160 \mu \mathrm{L}$ of $0.4 \mathrm{mM}$ DPPH methanolic solution was added. The absorbance was recorded at $517 \mathrm{~nm}$ after $30 \mathrm{~min}$ of incubation. Using Equation (1), the free radical scavenging activity of the mushroom polysaccharides was computed $[29,30]$ as:

$$
\mathrm{I}(\%)=\frac{A_{\text {control }}-A_{\text {sample }}}{A_{\text {control }}} \times 100 .
$$

\subsubsection{2,2'-azinobis-(3-ethylbenzothiazoline-6-sulfonic acid) $\left(\mathrm{ABTS}^{\bullet+}\right)$ Cation Assay}

The ABTS ${ }^{\bullet+}$ was generated by reacting $7 \mathrm{mM}$ ABTS solution of $\mathrm{H}_{2} \mathrm{O}$ and $2.45 \mathrm{mM}$ potassium persulfate, and incubated for $12 \mathrm{~h}$ in the dark at $25^{\circ} \mathrm{C}$ [29,31]. Before starting the experiment, the $\mathrm{ABTS}^{\bullet+}$ solution was diluted with ethanol so that the absorbance was $0.708 \pm 0.025$ at a wavelength of $734 \mathrm{~nm}[29,31]$. A $160 \mu \mathrm{L}$ solution of $\mathrm{ABTS}^{\bullet+}$ was added to $40 \mu \mathrm{L}$ of the sample solution in ethanol at different concentration ranges. After $10 \mathrm{~min}$, the 
percent inhibition at $734 \mathrm{~nm}$ was calculated for each concentration compared to the blank (ethanol) absorbance values [29,31,32]. The antioxidant potential was calculated according to Equation (1) [29,31,32].

\subsubsection{Cupric Reducing Antioxidant Capacity (CUPRAC) Assay}

The chromogenic redox compound utilized in this assay was a bis(neocuproine) copper(II) chelate [33,34]. At pH 7.0 of the solution, the absorbance of the $\mathrm{Cu}(\mathrm{I})$-chelate, which is due to the redox reaction with the reducing testing agent, was measured at $450 \mathrm{~nm}[33,34]$. The color was due to the formation of $\mathrm{Cu}(\mathrm{I})-\mathrm{NC}$ chelation. All the reaction conditions were at optimum levels $[33,34]$. Slight modifications were made to this assay for the Morchella polysaccharides [26,29]. In a multiwell plate, $50 \mu \mathrm{L}$ of $10 \mathrm{Mm} \mathrm{Cu}$ (II) solution, $50 \mu \mathrm{L}$ of $7.5 \mathrm{mM}$ neocuproine, and $60 \mu \mathrm{L}$ of ammonium acetate $\left(\mathrm{NH}_{4} \mathrm{Ac}\right)$ of $1 \mathrm{M}$ solutions at $\mathrm{pH} 7.0$ were added. To make the total volume $200 \mu \mathrm{L}, 40 \mu \mathrm{L}$ of polysaccharides of different concentration series were added to the respective wells on the plate $[26,29]$. After 60 min of incubation, the absorbance change in the test and blank samples was measured at $450 \mathrm{~nm}[26,29]$.

\subsection{Enzyme Inhibitory Activities}

\subsubsection{Anti-Acetylcholinesterase Activity}

The modified Ellman method was used for this assay using acetylcholinesterase (AChE) from electric eels and AChE iodide as a substrate [26,29,35]. Additionally, 5,5'Dithio-bis(2-nitrobenzoic) acid (DTNB) was utilized for cholinesterase action [26,29]. Then, $130 \mu \mathrm{L}$ of $100 \mathrm{mM}$ sodium phosphate buffer ( $\mathrm{pH} 8.0), 10 \mu \mathrm{L}$ of polysaccharide solution made in ethanol in a series of different concentrations, and $20 \mu \mathrm{L}$ of AChE solution in buffer were mixed and incubated for $15 \mathrm{~min}$ at room temperature, and $20 \mu \mathrm{L}$ of $0.5 \mathrm{mM}$ DTNB was added to them [26,29]. The reaction was then started by the addition of $20 \mu \mathrm{L}$ of $0.71 \mathrm{mM}$ of acetylthiocholine iodide [26,29]. The hydrolysis of the substrate was monitored at $412 \mathrm{~nm}$ by the formation of a yellow color 5-thio-2-nitrobenzoate anion that appears when DTNB reacts with thiocholine [26,29].

\subsubsection{Butyryl Cholinesterase Inhibition Assay}

The butyryl cholinesterase (BChE) inhibition assay was performed using BChE from horse serum (BChE, EC 3.1.1.8, $11.4 \mathrm{U} / \mathrm{mg}$, Sigma, St. Louis, MO, USA), and butyryl thiocholine iodide as its substrate, respectively, in a colorimetric analysis [36]. In total, $10 \mu \mathrm{L}$ of polysaccharide solution made in $0.2 \%$ DMSO, $79 \mu \mathrm{L}$ of $20 \mathrm{mM}$ sodium phosphate buffer ( $\mathrm{pH}$ 7.6), and $1 \mu \mathrm{L}$ of prepared enzymes (with final concentrations of $0.035 \mathrm{unit} / \mathrm{mL}$ for $\mathrm{BChE}$, and final concentrations of 1 to $500 / 1000 \mu \mathrm{M}$ for the compounds tested) were combined and incubated for $15 \mathrm{~min}[26,29,37]$. To the combined solutions, $10 \mu \mathrm{L}$ of substrate solution was added (final concentration of $4 \mathrm{mM}$ for butyryl thiocholine iodide) and incubated for $30 \mathrm{~min}[26,29,37]$. The reaction was halted by adding $900 \mu \mathrm{L}$ of DTNBphosphate-ethanol reagent and the absorbance was measured quickly at $412 \mathrm{~nm}$ on a microplate reader $[26,29,37]$. The percent inhibition at $50 \%\left(\mathrm{IC}_{50}\right)$ was calculated with galanthamine as a positive control $[26,29,37]$.

\subsubsection{Anti-Tyrosinase Assay}

Anti-tyrosinase activity was observed spectrophotometrically, as established by Masuda with some changes [38]. The tyrosinase enzyme from mushrooms was used with I-3,4-dihydroxyphenylalanine (I-DOPA) as a substrate in this reaction $[26,29,38]$. As such, $150 \mu \mathrm{L}$ of the $100 \mathrm{mM}$ sodium phosphate buffer (pH 6.8), $10 \mu \mathrm{L}$ of polysaccharide solution made in ethanol in a series of different concentrations, and $20 \mu \mathrm{L}$ of the tyrosinase solution in buffer were combined and placed for $10 \mathrm{~min}$ at $37^{\circ} \mathrm{C}$, and $20 \mu \mathrm{L}$ L-DOPA was supplemented to them $[26,29,38]$. The sample and blank absorbances were recorded at $475 \mathrm{~nm}$ using a 96-well microplate $[26,29,38]$. 


\subsubsection{Statistical Analysis}

The results obtained during different bioassays were the mean of the triplicate samples. The data were recorded as the mean, and the standard deviation was calculated for them. The Student's test was used here to get the main variation between the means, and $p$ values $<0.05$ were considered as significant.

\section{Results and Discussion}

\subsection{Polysaccharide Extraction}

The yield of the crude proteinized polysaccharide and deproteinized polysaccharides from $M$. esculenta fruiting bodies varied every time during the extraction process. These crude polysaccharides were a mixture of polysaccharides that varied in molecular weight. The average yield of the crude proteinized polysaccharides was 3\%, while that of deproteinized polysaccharides was $1.3 \%$, from the dried powdered fruiting body taken during each extraction experiment. The loss in yield occurred during various steps of the experiment that included the hot water extraction, ethanol washing steps, collection after drying in the oven, and deproteinization steps. Optimization of the extraction method can be useful for getting a better yield.

\subsection{FTIR Analysis}

The FTIR spectra of proteinized and deproteinized M. esculenta crude polysaccharides are presented in Figure 1a,b, respectively. In Figure 1a, the peaks at $3267 \mathrm{~cm}^{-1}$ in the proteinized polysaccharides, and $3427 \mathrm{~cm}^{-1}$ in the deproteinized polysaccharides FTIR spectrum of M. esculenta, revealed the existence of hydroxyl groups [39]. These bands come from the stretching of the hydroxyl groups. The band at $2918 \mathrm{~cm}^{-1}$ in the spectrum of proteinized polysaccharides, and at $2999 \mathrm{~cm}^{-1}$ and $2910 \mathrm{~cm}^{-1}$ in the spectrum of deproteinized crude polysaccharides of M. esculenta, were representative of the - $\mathrm{CH}$ stretching vibration band showing the presence of the polysaccharide. $\mathrm{N}-\mathrm{H}$ groups present in the proteinized polysaccharides of M. esculenta caused peaks at a frequency from $1618 \mathrm{~cm}^{-1}$ to $1525 \mathrm{~cm}^{-1}$. The bands' intensity for amide groups decreased for deproteinized polysaccharides because of the removal of proteins. However, a similar band at $1640 \mathrm{~cm}^{-1}$ represented the $\mathrm{C}=\mathrm{O}$ group of ester carbonyls studied by Li et al. [40]. In another study, a $1616 \mathrm{~cm}^{-1}$ band was also assigned to the $\mathrm{C}=\mathrm{O}$ group to represent the presence of uronic acid in $M$. esculenta polysaccharides [2]. The carbonyl group band appeared at $1657 \mathrm{~cm}^{-1}$ in the deproteinized polysaccharides. The removal of proteins caused a decreased in the intensity of both $\mathrm{N}-\mathrm{H}$ and $\mathrm{C}=\mathrm{O}$ groups in the deproteinized polysaccharides. The $1398 \mathrm{~cm}^{-1}$ peak can be assigned to the presence of galactans, as previously reported for the $1400 \mathrm{~cm}^{-1}$ peak in the M. esculenta crude polysaccharides [2]. Similar bands at 1433 and $1406 \mathrm{~cm}^{-1}$, representing galactans, were also present in the deproteinized polysaccharides (Figure 1b).The large peak at $1003.15 \mathrm{~cm}^{-1}$ was almost similar to the $1050 \mathrm{~cm}^{-1}$ peak reported by $\mathrm{Li}$ et al. for the $-\mathrm{C}-\mathrm{O}$ group [40]. The shoulder at $875.33 \mathrm{~cm}^{-1}$ can be assigned to the $\beta$-glycosidic bond. This $\beta$-glycosidic bond peak was also reported at $890 \mathrm{~cm}^{-1}$ by other authors [40]. It has been suggested that this $\beta$-glycosidic linkage plays a role in the antitumor and immunomodulatory functions of the Morchella polysaccharides [40]. The small shoulder from 600 to $400 \mathrm{~cm}^{-1}$ is usually that of the pyranose structure in the polysaccharides. It was reported earlier from $\mathrm{C}^{13}$-NMR that $M$. esculenta polysaccharides are rich in glucose, mannose, and galactose, while small amounts of arabinose, rhamnose, and xylose are also present, and arranged through 1-3 and 1-4 $\beta$-linkages [40]. 


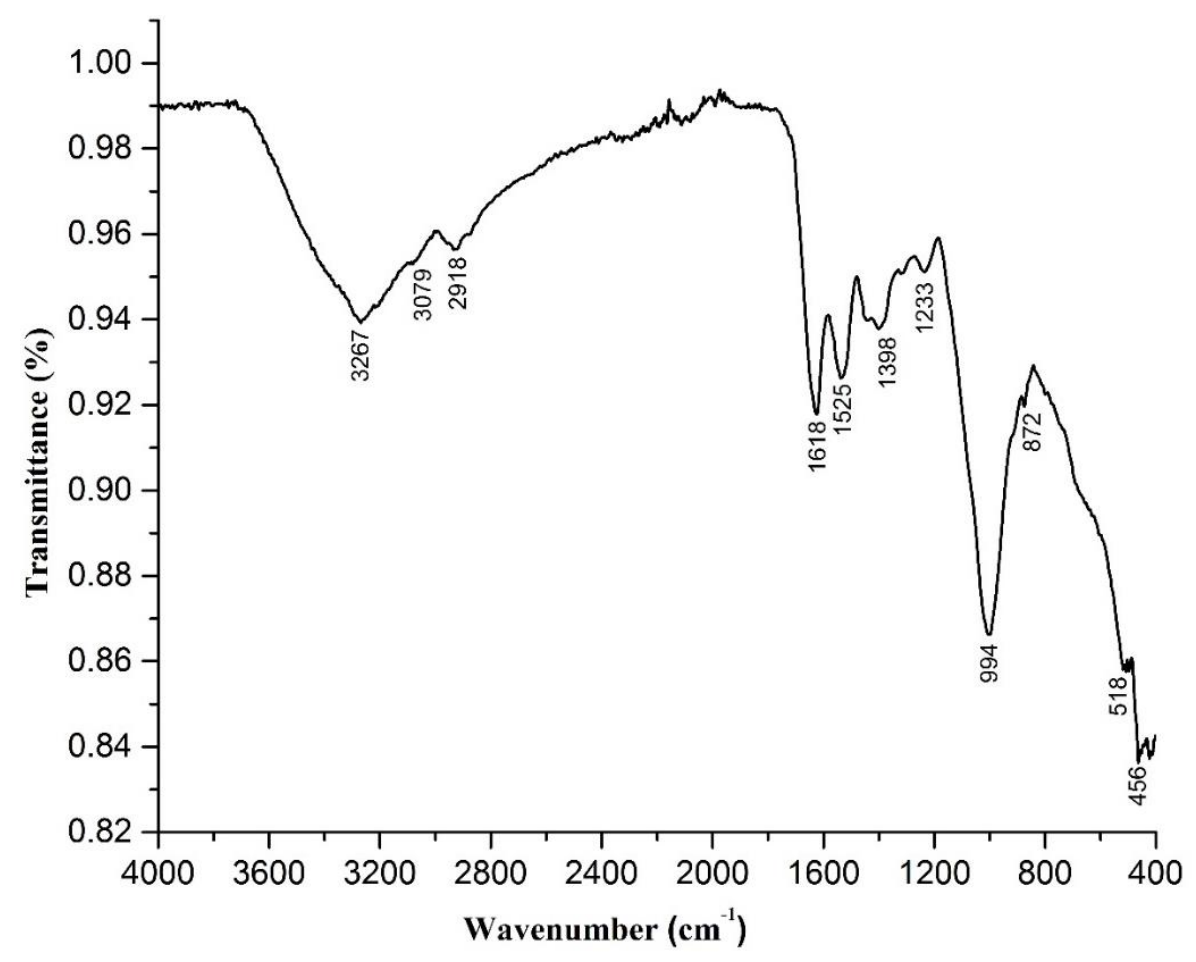

(a)

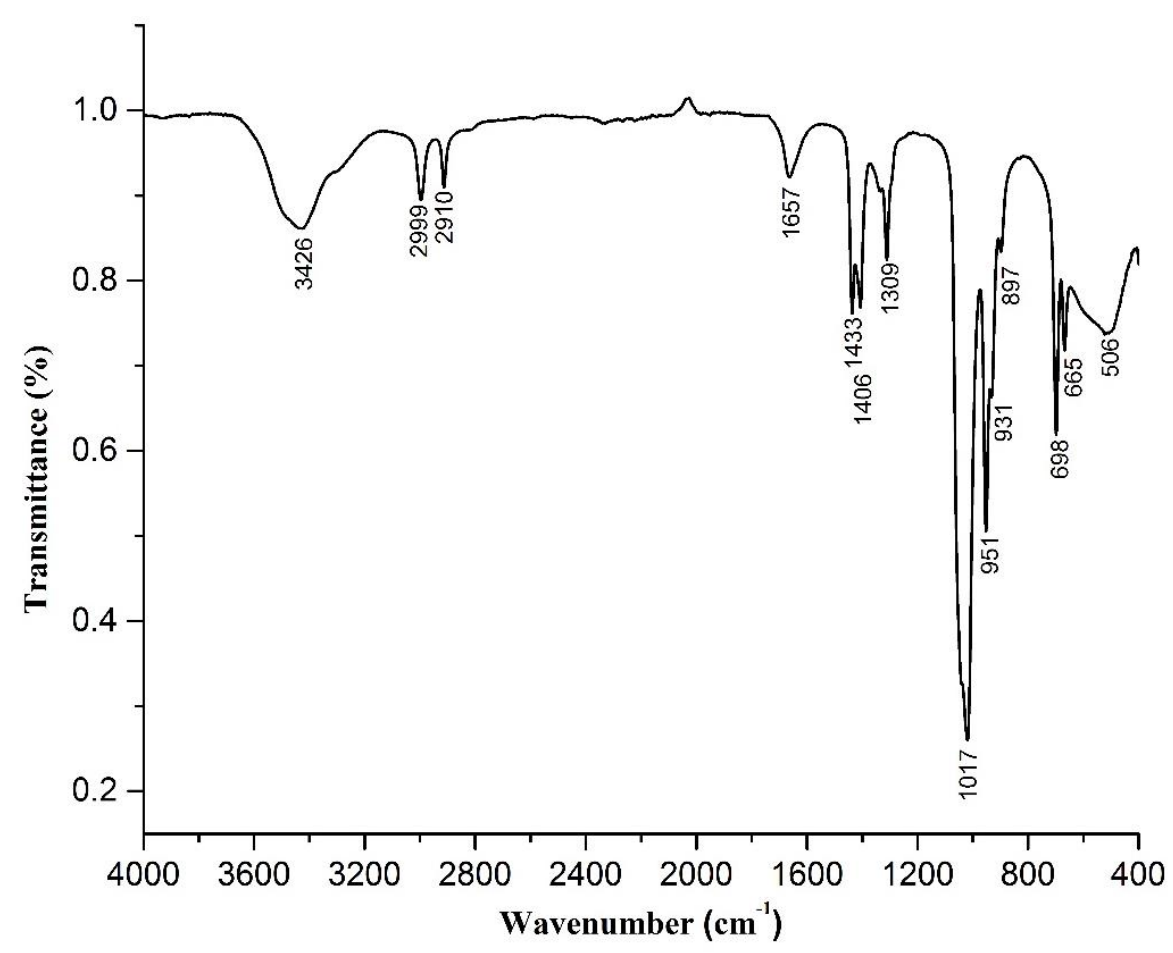

(b)

Figure 1. (a) Fourier transform infrared spectroscopy (FTIR) spectrum of proteinized forms of polysaccharides of M. esculenta. (b) FTIR spectrum of deproteinized forms of polysaccharides of M. esculenta.

From the deproteinized polysaccharide FTIR spectrum (Figure 1b), several new features could be observed, and several peak intensities were enhanced compared to the proteinized polysaccharide spectrum. At $1664.01 \mathrm{~cm}^{-1}$, a small shoulder revealed the existence 
of carbon-carbon double bonds $(\mathrm{C}=\mathrm{C})$ of deproteinized polysaccharides of M. esculenta. The peaks in the FTIR spectrum of the deproteinized crude polysaccharides of M. esculenta at $1436 \mathrm{~cm}^{-1}$ to $1310 \mathrm{~cm}^{-1}$ represented the bending vibrations of the $\mathrm{O}-\mathrm{H}$ groups. The high intensity bands located between $1320 \mathrm{~cm}^{-1}$ and $1003 \mathrm{~cm}^{-1}$ in the proteinized crude polysaccharides from $M$. esculenta depict the pyranose rings, and the region of $1019 \mathrm{~cm}^{-1}$ in the monosaccharide also showed similar peaks. The main bands in the spectrum of proteinized crude polysaccharides centered at $875 \mathrm{~cm}^{-1}, 898 \mathrm{~cm}^{-1}$, and $898.21 \mathrm{~cm}^{-1}$, and the deproteinized crude polysaccharides from M. esculenta indicated the presence of $\beta$-type linked glycosidic bonds.

\subsection{Antioxidant Activity}

The consumption of antioxidant-containing fruits and vegetables is important for living organisms, and particularly for humans, as antioxidants defend the body from destruction by reactive oxygen species (ROS). Excessive generation of ROS and imbalanced metabolism can lead to a condition of oxidative stress, resulting in severe impairments and disorders like Alzheimer's disease, Parkinson's disease, and several other diseases due to the damage of proteins, DNA, and other biomolecules. The antioxidant properties of secondary metabolites, extracted through hot water and ethanolic extract from mushroom species, for example Boletus, Agaricus, and Agrocybe, have been well described. These mushrooms are used in different foodstuffs as a flavoring ingredient. Three different antioxidant assays were performed to test the antioxidant potential of the isolated polysaccharides from M. esculenta. These antioxidant assays included the DPPH, ABTS, and CUPRAC assays.

\subsubsection{DPPH Assay}

In the DPPH bioassay, the radical hunting power of the proteinized and deproteinized polysaccharides from $M$. esculenta was evaluated and compared with the reference compounds $\alpha$-tocopherol and butylated hydroxyanisole (BHA). The DPPH assay revealed that the radical scavenging activity of the deproteinized polysaccharides of these wild-collected morels contained moderate antioxidant activity that was concentration dependent. In contrast, the proteinized polysaccharides from M. esculenta had no antioxidant activity at any of the tested concentrations. The deproteinized polysaccharide samples of $M$. esculenta displayed potent antioxidant activity and the trend of antioxidant potential was concentration dependent, as shown in Table 1 . The $\mathrm{IC}_{50}$ value of deproteinized polysaccharides of Morchella esculenta was $282.95 \mu \mathrm{g} \cdot \mathrm{mL}^{-1}$, compared to the reference compounds BHA and $\alpha$-tocopherols, which were $37.20 \pm 0.41$ and $19.80 \pm 0.36 \mu \mathrm{g} \cdot \mathrm{mL}^{-1}$, respectively. The lower values of $\mathrm{IC}_{50}$ obtained here for the deproteinized polysaccharides compared to the standard BHA and tocopherol are due to the large molecular weight of these biopolymers, the hydrogen addition or removal strength, and the different electron donating and accepting properties. Different glucans isolated from Lentinula edodes (Shiitake mushrooms) have an $\mathrm{IC}_{50}$ of $183.8 \mu \mathrm{g} / \mathrm{mL}$, which is almost similar to the antioxidant values we reported here for M. esculenta [41]. Xiong et al. reported DPPH activity with an $\mathrm{EC}_{50}$ value of $1.18 \pm 0.04 \mathrm{mg} / \mathrm{mL}$ for crude polysaccharides from M. importuna, which was lower than the standard compound [42].

\subsubsection{ABTS •+ Assay}

The ABTS bioassay is a useful method for defining the antioxidant potential of $\mathrm{H}$-atom donating and chain-breaking antioxidants. The ABTS antioxidant activity of the isolated polysaccharides was tested and compared with the reference antioxidants BHA and $\alpha$ tocopherol. The $\mathrm{IC}_{50}$ values of some polysaccharides were near the range of the reference standards, while some polysaccharides showed weak activity, as their percent inhibition was lower than the standards, and their $\mathrm{IC}_{50}$ values were higher than the reference standard compounds. Table 1 indicates that the morels' proteinized polysaccharides were slightly active at various concentrations. The deproteinized polysaccharides of M. esculenta displayed moderate antioxidant activity in comparison with the proteinized polysaccharides, 
as presented in Table 1. In terms of the $\mathrm{IC}_{50}$ value, the deproteinized polysaccharides of M. esculenta was $130.69 \mu \mathrm{g} \cdot \mathrm{mL}^{-1}$. In comparison, the reference standard compounds BHA and $\alpha$-tocopherol showed $\mathrm{IC}_{50}$ values of 38.51 and $11.82 \mu \mathrm{g} \cdot \mathrm{mL}^{-1}$, respectively. The reported $M$. esculenta mycelium hot water-ethanolic extract had a $\mathrm{IC}_{50}$ value of $87.50 \pm 4.33$ and this extract possibly contained flavonoids, phenols, and other small organic molecules [43].

Table 1. 2,2-diphenyl-1-picrylhydrazyl (DPPH), 2,2'-azinobis-(3-ethylbenzothiazoline-6-sulfonic acid) (ABTS) cation and cupric reducing antioxidant capacity (CUPRAC) free radical scavenging activity of polysaccharides of M. esculenta.

\begin{tabular}{|c|c|c|c|c|c|}
\hline \multicolumn{6}{|c|}{ DPPH Assay } \\
\hline Polysaccharides Sample & $50 \mu \mathrm{g} / \mathrm{mL}$ & $100 \mu \mathrm{g} / \mathrm{mL}$ & $200 \mu \mathrm{g} / \mathrm{mL}$ & $400 \mu \mathrm{g} / \mathrm{mL}$ & $\mathrm{IC}_{50}(\mu \mathrm{g} / \mathrm{mL})$ \\
\hline Proteinized & NA & NA & NA & NA & NA \\
\hline Deproteinized & $7.88 \pm 1.87$ & $21.87 \pm 0.90$ & $40.96 \pm 1.68$ & $66.92 \pm 2.58$ & 282.95 \\
\hline BHA & $79.37 \pm 0.33$ & $86.21 \pm 0.16$ & $87.13 \pm 0.09$ & $87.27 \pm 0.03$ & $37.20 \pm 0.41$ \\
\hline$\alpha$-Tocopherol & $66.68 \pm 0.43$ & $87.28 \pm 0.13$ & $87.14 \pm 0.28$ & $87.44 \pm 0.09$ & $19.80 \pm 0.36$ \\
\hline \multicolumn{6}{|c|}{ ABTS Cation Assay } \\
\hline Polysaccharides Sample & $50 \mu \mathrm{g} / \mathrm{mL}$ & $100 \mu \mathrm{g} / \mathrm{mL}$ & $200 \mu \mathrm{g} / \mathrm{mL}$ & $400 \mu \mathrm{g} / \mathrm{mL}$ & $\mathrm{IC}_{50} \mu \mathrm{g} / \mathrm{mL}$ \\
\hline Proteinized & $4.71 \pm 0.50$ & $7.37 \pm 0.72$ & $10.89 \pm 2.87$ & $19.32 \pm 2.14$ & $>400$ \\
\hline Deproteinized & $25.78 \pm 1.53$ & $41.32 \pm 1.09$ & $69.60 \pm 1.07$ & $82.96 \pm 2.23$ & 130.69 \\
\hline BHA & $90.79 \pm 0.19$ & $91.02 \pm 0.05$ & $91.50 \pm 0.20$ & $91.18 \pm 0.26$ & $38.51 \pm 0.54$ \\
\hline$\alpha$-Tocopherol & $66.52 \pm 3.77$ & $88.80 \pm 2.57$ & $91.95 \pm 0.09$ & $91.86 \pm 0.12$ & $11.82 \pm 0.09$ \\
\hline \multicolumn{6}{|c|}{ CUPRAC Assay } \\
\hline Polysaccharides Sample & $50 \mu \mathrm{g} / \mathrm{mL}$ & $100 \mu \mathrm{g} / \mathrm{mL}$ & $200 \mu \mathrm{g} / \mathrm{mL}$ & $400 \mu \mathrm{g} / \mathrm{mL}$ & $A_{0.50} \mu \mathrm{g} / \mathrm{mL}$ \\
\hline Proteinized & $0.12 \pm 0.01$ & $0.14 \pm 0.01$ & $0.22 \pm 0.04$ & $0.30 \pm 0.03$ & $>400$ \\
\hline Deproteinized & $0.18 \pm 0.02$ & $0.28 \pm 0.03$ & $0.46 \pm 0.04$ & $0.84 \pm 0.03$ & 215.79 \\
\hline BHA & $0.95 \pm 0.11$ & $1.52 \pm 0.11$ & $2.47 \pm 0.01$ & $3.59 \pm 0.07$ & $66.72 \pm 0.81$ \\
\hline$\alpha$-Tocopherol & $0.35 \pm 0.11$ & $0.54 \pm 0.17$ & $0.85 \pm 0.02$ & $1.51 \pm 0.04$ & $24.40 \pm 0.69$ \\
\hline
\end{tabular}

\subsubsection{CUPRAC Assay}

The CUPRAC antioxidant assay of the mushroom polysaccharides was performed and compared with the reference compounds BHA and $\alpha$-tocopherol. The CUPRAC assay showed that the antioxidant potential of the mushroom polysaccharides was dependent on its concentration, increasing with increasing concentration. The reference compounds BHA and $\alpha$-tocopherol had absorbances at $0.5\left(\mathrm{~A}_{0.5}\right)$ of 66.72 and $24.40 \mu \mathrm{g} / \mathrm{mL}$, respectively. In Table 1, the CUPRAC assay results demonstrate that the polysaccharides in both forms had reasonable free radical scavenging activities, in contrast to BHA and $\alpha$-Tocopherol. The $A_{0.5}$ values of the deproteinized samples were better than that of the proteinized crude polysaccharides. Thus, the deproteinized samples were more active in the CUPRAC assay. A similar moderate antioxidant activity was also observed in Morchella mushrooms from China, together with immune-enhancing properties [44]. An exopolysaccharide from a submerged culture of $M$. esculenta showed potent antioxidant activities in an in vivo experiment [45]. The antioxidant and neuroprotective roles of crude polysaccharides from M. importuna have also been observed previously, and it was suggested that they can enhance the function of radical scavenging enzymes in the body [42].

\subsection{Enzyme Inhibition Assays}

\subsubsection{Acetylcholinesterase (AChE) Inhibitory Activity}

Acetylcholinesterase functions by breaking acetylcholine and other choline esters used as neurotransmitters, hence inhibition of this enzyme prolongs the lifetime of these neurotransmitters [46]. In Alzheimer's disease, the expression of this enzyme increases, and the hydrolysis rate of AChE also increases [47]. Data collected for the proteinized and deproteinized polysaccharides of the M. esculenta mushroom are presented in Table 2. 
Galanthamine was used as a reference standard in the enzyme inhibition assay for acetylcholinesterase. The proteinized polysaccharides of M. esculenta showed better blocking of the enzyme compared to the deproteinized polysaccharides. The $\mathrm{IC}_{50}$ values of both samples of $M$. esculenta were higher than $100 \mu \mathrm{g} \cdot \mathrm{mL}^{-1}$ as compared to the standard galanthamine, which had an $\mathrm{IC}_{50}$ of $5.0 \pm 0.13 \mu \mathrm{g} \cdot \mathrm{mL}^{-1}$ (Table 2). These data show the proteinized polysaccharides of $M$. esculenta were low to moderately potent for blocking $\mathrm{AChE}$ function when compared to the standard galanthamine. We can therefore infer that Morchella polysaccharides have therapeutic potential and could be used in conjugation with other drugs to control Alzheimer's disease and other related neurological diseases.

Table 2. Acetylcholinesterase (AChE) and butyryl cholinesterase (BChE) inhibitory assay of polysaccharides of M. esculenta.

\begin{tabular}{|c|c|c|c|c|c|}
\hline \multicolumn{6}{|c|}{ Acetylcholinesterase Inhibition Assay } \\
\hline Polysaccharides Samples & $12.5 \mu \mathrm{g} / \mathrm{mL}$ & $25 \mu \mathrm{g} / \mathrm{mL}$ & $50 \mu \mathrm{g} / \mathrm{mL}$ & $100 \mu \mathrm{g} / \mathrm{mL}$ & $\mathrm{IC}_{50} \mu \mathrm{g} / \mathrm{mL}$ \\
\hline Proteinized & $18.72 \pm 2.17$ & $28.68 \pm 2.13$ & $33.38 \pm 2.57$ & $39.67 \pm 2.11$ & $>100$ \\
\hline Deproteinized & $2.64 \pm 1.44$ & $3.51 \pm 2.12$ & $17.45 \pm 0.95$ & $20.54 \pm 0.50$ & $>100$ \\
\hline Galanthamine & $55.31 \pm 0.79$ & $55.87 \pm 0.97$ & $61.66 \pm 1.17$ & $55.31 \pm 0.79$ & $5.0 \pm 0.13$ \\
\hline \multicolumn{6}{|c|}{ Butyryl Cholinesterase Inhibition Assay } \\
\hline Polysaccharides Samples & $12.5 \mu \mathrm{g} / \mathrm{mL}$ & $25 \mu \mathrm{g} / \mathrm{mL}$ & $50 \mu \mathrm{g} / \mathrm{mL}$ & $100 \mu \mathrm{g} / \mathrm{mL}$ & $\mathrm{IC}_{50} \mu \mathrm{g} / \mathrm{mL}$ \\
\hline Proteinized & $14.96 \pm 1.81$ & $38.25 \pm 1.96$ & $45.11 \pm 2.08$ & $48.22 \pm 2.28$ & 128.62 \\
\hline Deproteinized & $44.65 \pm 2.66$ & $49.61 \pm 2.76$ & $52.22 \pm 2.75$ & $54.08 \pm 2.88$ & 28.74 \\
\hline Galanthamine & $50.88 \pm 1.42$ & $62.48 \pm 0.02$ & $66.47 \pm 0.46$ & $71.43 \pm 0.06$ & $11.55 \pm 0.93$ \\
\hline
\end{tabular}

\subsubsection{Butyryl Cholinesterase Inhibition Assay}

$\mathrm{BChE}$ is another common and broad cholinesterase that uses choline esters as its substrates [26]. Inside the human body, BChE exists in organs including the liver, and also in blood plasma. We performed the $\mathrm{BChE}$ assay using galanthamine as a reference compound [26]. Blockers of cholinesterase from different mushrooms are undiscovered therapeutic agents that could be used for the treatment of neurodegenerative diseases, and likely have vast medicinal abilities [26]. The proteinized polysaccharides of $M$. esculenta were weakly inhibitive when used in smaller amounts, while they were more potent at higher concentrations (Table 2). The deproteinized sample of $M$. esculenta displayed higher potency. The $\mathrm{IC}_{50}$ value of the proteinized polysaccharides of $M$. esculenta was $128.62 \mu \mathrm{g} \cdot \mathrm{mL}^{-1}$ and the value of the deproteinized samples was $28.74 \mu \mathrm{g} \cdot \mathrm{mL}^{-1}$, while that of the standard galanthamine was $\mathrm{IC}_{50} 11.55 \pm 0.93 \mu \mathrm{g} \cdot \mathrm{mL}^{-1}$. The lower inhibitory power of the polysaccharides compared to the standard compound might be due to their binding capacity, depending on the size of the active pocket of the enzyme and the interaction between the enzyme and the tested inhibitor. Although the galanthamine has two-fold higher butyryl cholinesterase inhibition than the deproteinized polysaccharide, both these polysaccharides are suitable bionutrients due to lower toxic nature.

\subsubsection{Tyrosinase Enzyme Inhibition}

We also tested the isolated polysaccharides for their tyrosinase enzyme inhibition activity using kojic acid as a reference standard. Table 3 shows that the M. esculenta mushroom proteinized polysaccharides had no activity at the initial concentrations, but were weakly inhibitive at higher concentrations. The deproteinized polysaccharides of M. esculenta also showed no repression at the initial concentrations; however, weak repression was observed at $100 \mu \mathrm{g} / \mathrm{mL}$. The $\mathrm{IC}_{50}$ values for the $M$. esculenta proteinized and deproteinized polysaccharides were above $100 \mu \mathrm{g} \cdot \mathrm{mL}^{-1}$, while that of the standard kojic acid was $8.25 \pm 0.36 \mu \mathrm{g} \cdot \mathrm{mL}^{-1}$. These higher $\mathrm{IC}_{50}$ values for the polysaccharides of M. esculenta indicated that they did not interact with the binding pocket of the tyrosinase enzymes as compared to the kojic acid, which may be because of their higher molecular weight, or that they cannot induced any changes in the enzyme when they interacted with 
it. These results showed that the M. esculenta polysaccharides do not have any effect on skin pigmentation and melatonin metabolism.

Table 3. Tyrosinase enzyme inhibition assay of polysaccharides from M. esculenta.

\begin{tabular}{|c|c|c|c|c|c|}
\hline Polysaccharides Samples & $12.5 \mu \mathrm{g} / \mathrm{mL}$ & $25 \mu \mathrm{g} / \mathrm{mL}$ & $50 \mu \mathrm{g} / \mathrm{mL}$ & $100 \mu \mathrm{g} / \mathrm{mL}$ & $\mathrm{IC}_{50}(\mu \mathrm{g} / \mathrm{mL})$ \\
\hline Proteinized & NA & $4.87 \pm 0.89$ & $16.12 \pm 2.70$ & $31.99 \pm 2.32$ & $>100$ \\
\hline Deproteinized & NA & NA & NA & $10.94 \pm 1.55$ & $>100$ \\
\hline Kojic acid & $50.49 \pm 1.32$ & $52.36 \pm 0.81$ & $56.98 \pm 0.96$ & $67.89 \pm 1.05$ & $8.25 \pm 0.36$ \\
\hline
\end{tabular}

\section{Conclusions}

Polysaccharides, particularly $\beta$-glucans, strengthen the immune system and are found in high levels in mushrooms. Therefore, many mushroom species are both a valuable dietary source as well as a possible therapeutic source for treating prevalent disorders like cancer, inflammation, and diabetes. The preliminary outcome of this research showed that the crude polysaccharides of the selected mushroom species M. esculenta had notable antioxidant potential, specifically the deproteinized crude polysaccharides. Thus, this mushroom genus is a suitable source of antioxidants and anticancer agents. Based on the state-of-the-art knowledge about the antioxidant potential, the enzyme inhibitory test against acetylcholinesterase and butyryl cholinesterase enzymes, the fruiting bodies, and the polysaccharides and other secondary metabolites present in them, mushrooms are potentially useful agents for the treatment of Alzheimer's disease and other related neurological diseases. The regular consumption of this mushroom may also help in the enhancement of cognition abilities and memory in old age and provide a good nutrition. Moreover, the further investigation of the properties of other metabolites present within the discussed mushroom species needs to be undertaken in order to fully characterize their value as nutrients for humans.

Author Contributions: S.L.B. supervised and interpretation of the research work and wrote the manuscript. A.R. performed in the initial task of isolation and purification of polysaccharides and wrote an initial draft for her thesis. A.M. and N.A. collected the mushrooms and helped in experimental design. G.T.Ç., F.Ç. and M.E.D. performed the bioassays. A.-H.E. and M.J. assisted in interpretation of results and drafting the manuscript and editing its different versions. All authors have read and agreed to the published version of the manuscript.

Funding: We appreciate King Abdullah University of Science and Technology, Saudi Arabia for their support.

Institutional Review Board Statement: Not applicable.

Informed Consent Statement: Informed consent was obtained from all subjects involved in the study.

Data Availability Statement: Data will be provided upon request.

Conflicts of Interest: The authors declare no conflict of interest.

\section{References}

1. Ren, L.; Perera, C.; Hemar, Y. Antitumor activity of mushroom polysaccharides: A review. Food Funct. 2012, 3, 1118-1130. [CrossRef]

2. Liu, C.; Sun, Y.; Mao, Q.; Guo, X.; Li, P.; Liu, Y.; Xu, N. Characteristics and antitumor activity of Morchella esculenta polysaccharide extracted by pulsed electric field. Int. J. Mol. Sci. 2016, 17, 986. [CrossRef]

3. Pala, S.A.; Wani, A.H. Mushrooms: The entities with multifarious medicinal properties. J. Pharm. Res. 2011, 4, 4721-4726.

4. Hobbs, C. Medicinal Value of Turkey Tail Fungus Trametes versicolor (L.:Fr.) Pilat (Aphyllophoromycetideae). A Literature Review. Int. J. Med. Mushrooms 2004, 6, 195-218. [CrossRef]

5. Schepetkin, I.A.; Quinn, M.T. Botanical polysaccharides: Macrophage immunomodulation and therapeutic potential. Int. Immunopharmacol. 2006, 6, 317-333. [CrossRef]

6. Wasser, S.P.; Weis, A.L. Medicinal Properties of Substances Occurring in Higher Basidiomycetes Mushrooms: Current Perspectives (Review). Int. J. Med. Mushrooms 1999, 1, 31-62. [CrossRef] 
7. Abeytunga, D.T.U. Biological activities of pleurotus mushrooms. In Mushrooms: Types, Properties and Nutrition; Nova Science Pub Inc.: Hauppauge, NY, USA, 2012; pp. 329-350, ISBN 9781614701101.

8. Wasser, S.P. Medicinal mushrooms in human clinical studies. Part I. anticancer, oncoimmunological, and immunomodulatory activities: A review. Int. J. Med. Mushrooms 2017, 19, 279-317. [CrossRef]

9. C.Ooi, V.; Liu, F. Immunomodulation and Anti-Cancer Activity of Polysaccharide-Protein Complexes. Curr. Med. Chem. 2012, 7, 715-729. [CrossRef] [PubMed]

10. Gargano, M.L.; van Griensven, L.J.L.D.; Isikhuemhen, O.S.; Lindequist, U.; Venturella, G.; Wasser, S.P.; Zervakis, G.I. Medicinal mushrooms: Valuable biological resources of high exploitation potential. Plant Biosyst. 2017, 151, 548-565. [CrossRef]

11. Lemieszek, M.; Rzeski, W. Anticancer properties of polysaccharides isolated from fungi of the Basidiomycetes class. Wspolczesna Onkol. 2012, 16, 285-289. [CrossRef] [PubMed]

12. Cruz, A.; Pimentel, L.; Rodríguez-Alcalá, L.M.; Fernandes, T.; Pintado, M. Health Benefits of Edible Mushrooms Focused on Coriolus versicolor: A Review. J. Food Nutr. Res. 2016, 4, 773-871. [CrossRef]

13. Halpern, G.M. Medicinal mushrooms. Prog. Nutr. 2010, 12, 29-36. [CrossRef]

14. Van Griensven, L.J.L.D.; Shnyreva, A.V.; Song, W. Extracts of medicinal mushrooms agaricus bisporus and phellinus linteus induce proapoptotic effects in the human leukemia cell line K562. Int. J. Med. Mushrooms 2010, 12, 167-175. [CrossRef]

15. Yarlagadda, R.; Lemma, T.; Wolde-Mariam, M.; Gebrelibanos, M.; Sintayehu, B.; Ahmed, S.M. A systematic review on some medicinal mushrooms showing antioxidant and anticancer activities. Med. Data 2013, 5, 253-260.

16. Duncan, C.J.G.; Pugh, N.; Pasco, D.S.; Ross, S.A. Isolation of a galactomannan that enhances macrophage activation from the edible fungus Morchella esculenta. J. Agric. Food Chem. 2002. [CrossRef] [PubMed]

17. Heleno, S.A.; Stojković, D.; Barros, L.; Glamočlija, J.; Soković, M.; Martins, A.; Queiroz, M.J.R.P.; Ferreira, I.C.F.R. A comparative study of chemical composition, antioxidant and antimicrobial properties of Morchella esculenta (L.) Pers. from Portugal and Serbia. Food Res. Int. 2013, 51, 236-243. [CrossRef]

18. Huo, W.; Qi, P.; Cui, L.; Zhang, L.; Dai, L.; Liu, Y.; Hu, S.; Feng, Z.; Qiao, T.; Li, J. Polysaccharide from wild morels alters the spatial structure of gut microbiota and the production of short-chain fatty acids in mice. Biosci. Microbiota Food Health 2020, 39, 219-226. [CrossRef]

19. Yang, H.; Yin, T.; Zhang, S. Isolation, purification, and characterization of polysaccharides from wide Morchella esculenta (L.) pers. Int. J. Food Prop. 2015, 18, 1385-1390. [CrossRef]

20. Lee, S.R.; Roh, H.S.; Lee, S.; Park, H.B.; Jang, T.S.; Ko, Y.J.; Baek, K.H.; Kim, K.H. Bioactivity-guided isolation and chemical characterization of antiproliferative constituents from morel mushroom (Morchella esculenta) in human lung adenocarcinoma cells. J. Funct. Foods 2018, 40, 249-260. [CrossRef]

21. Hu, M.; Chen, Y.; Wang, C.; Cui, H.; Duan, P.; Zhai, T.; Yang, Y.; Li, S. Induction of apoptosis in HepG2 cells by polysaccharide MEP-II from the fermentation broth of Morchella esculenta. Biotechnol. Lett. 2013, 35, 1-10. [CrossRef]

22. Cai, Z.N.; Li, W.; Mehmood, S.; Pan, W.J.; Wu, Q.X.; Chen, Y.; Lu, Y.M. Effect of polysaccharide FMP-1 from Morchella esculenta on melanogenesis in B16F10 cells and zebrafish. Food Funct. 2018, 9, 5007-5015. [CrossRef]

23. Cui, H.L.; Chen, Y.; Wang, S.S.; Kai, G.Q.; Fang, Y.M. Isolation, partial characterisation and immunomodulatory activities of polysaccharide from Morchella esculenta. J. Sci. Food Agric. 2011, 91, 2180-2185. [CrossRef] [PubMed]

24. Huang, M.; Zhang, S.; Zhang, M.; Ou, S.; Pan, Z. Effects of polysaccharides from Morchella conica on nitric oxide production in lipopolysaccharide-treated macrophages. Appl. Microbiol. Biotechnol. 2012. [CrossRef]

25. Li, Y.; Yuan, Y.; Lei, L.; Li, F.; Zhang, Y.; Chen, J.; Zhao, G.; Wu, S.; Yin, R.; Ming, J. Carboxymethylation of polysaccharide from Morchella angusticepes Peck enhances its cholesterol-lowering activity in rats. Carbohydr. Polym. 2017. [CrossRef]

26. Tel, G.; Ozturk, M.; Duru, M.E.; Turkoglu, A. Antioxidant and anticholinesterase activities of five wild mushroom species with total bioactive contents. Pharm. Biol. 2015, 53, 824-830. [CrossRef]

27. Deveci, E.; Tel-Çayan, G.; Duru, M.E.; Öztürk, M. Isolation, characterization, and bioactivities of compounds from Fuscoporia torulosa mushroom. J. Food Biochem. 2019. [CrossRef] [PubMed]

28. Foti, M.C.; Daquino, C.; Geraci, C. Electron-Transfer Reaction of Cinnamic Acids and Their Methyl Esters with the DPPH. Radical in Alcoholic Solutions. J. Org. Chem. 2004, 69, 2309-2314. [CrossRef] [PubMed]

29. Deveci, E.; Tel-çayan, G.; Duru, M.E. Phenolic profile, antioxidant, anticholinesterase, and anti-tyrosinase activities of the various extracts of ferula elaeochytris and sideritis stricta. Int. J. Food Prop. 2018. [CrossRef]

30. Mohammed, S.A.A.; Khan, R.A.; El-readi, M.Z.; Emwas, A.H.; Sioud, S.; Poulson, B.G.; Jaremko, M.; Eldeeb, H.M.; Al-omar, M.S.; Mohammed, H.A. Suaeda vermiculata aqueous-ethanolic extract-based mitigation of ccl4-induced hepatotoxicity in rats, and hepg-2 and hepg-2/adr cell-lines-based cytotoxicity evaluations. Plants 2020, 9, 1291. [CrossRef]

31. Re, R.; Pellegrini, N.; Proteggente, A.; Pannala, A.; Yang, M.; Rice-Evans, C. Antioxidant activity applying an improved ABTS radical cation decolorization assay. Free Radic. Biol. Med. 1999. [CrossRef]

32. Öztürk, M.; Kolak, U.; Topu, G.; Öksüz, S.; Choudhary, M.I. Antioxidant and anticholinesterase active constituents from Micromeria cilicica by radical-scavenging activity-guided fractionation. Food Chem. 2011, 126, 31-38. [CrossRef]

33. Apak, R.; Güçlü, K.; Özyürek, M.; Karademir, S.E. Novel total antioxidant capacity index for dietary polyphenols and vitamins C and E, using their cupric ion reducing capability in the presence of neocuproine: CUPRAC method. J. Agric. Food Chem. 2004, 52, 7970-7981. [CrossRef] 
34. Apak, R.; Güçlü, K.; Demirata, B.; Özyürek, M.; Çelik, S.E.; Bektaşoğlu, B.; Berker, K.I.; Özyurt, D. Comparative evaluation of various total antioxidant capacity assays applied to phenolic compounds with the CUPRAC assay. Molecules 2007, 12, 1496-1547. [CrossRef]

35. Ellman, G.L.; Courtney, K.D.; Andres, V.; Featherstone, R.M. A new and rapid colorimetric determination of acetylcholinesterase activity. Biochem. Pharmacol. 1961, 7, 88-90. [CrossRef]

36. Tel, G.; Öztürk, M.; Duru, M.E.; Doğan, B.; Harmandar, M. Fatty acid composition, antioxidant, anticholinesterase and tyrosinase inhibitory activities of four Serratula species from anatolia. Rec. Nat. Prod. 2013, 7, 86-95.

37. Altaf, A.A.; Kausar, S.; Hamayun, M.; Lal, B.; Tahir, M.N.; Badshah, A. Ferrocenylaniline based amide analogs of methoxybenzoic acids: Synthesis, structural characterization and butyrylcholinesterase (BChE) inhibition studies. J. Mol. Struct. 2017. [CrossRef]

38. Masuda, T.; Yamashita, D.; Takeda, Y.; Yonemori, S. Screening for tyrosinase inhibitors among extracts of seashore plants and identification of potent inhibitors from Garcinia subelliptica. Biosci. Biotechnol. Biochem. 2005, 69, 197-201. [CrossRef]

39. Dhahri, M.; Sioud, S.; Dridi, R.; Hassine, M.; Boughattas, N.A.; Almulhim, F.; Al Talla, Z.; Jaremko, M.; Emwas, A.H.M. Extraction, Characterization, and Anticoagulant Activity of a Sulfated Polysaccharide from Bursatella leachii Viscera. ACS Omega 2020, 5 , 14786-14795. [CrossRef] [PubMed]

40. Li, S.; Gao, A.; Dong, S.; Chen, Y.; Sun, S.; Lei, Z.; Zhang, Z. Purification, antitumor and immunomodulatory activity of polysaccharides from soybean residue fermented with Morchella esculenta. Int. J. Biol. Macromol. 2017, 96, 26-34. [CrossRef] [PubMed]

41. Morales, D.; Rutckeviski, R.; Villalva, M.; Abreu, H.; Soler-Rivas, C.; Santoyo, S.; Iacomini, M.; Smiderle, F.R. Isolation and comparison of $\alpha$ - and $\beta$-D-glucans from shiitake mushrooms (Lentinula edodes) with different biological activities. Carbohydr. Polym. 2020. [CrossRef]

42. Xiong, C.; Li, Q.; Chen, C.; Chen, Z.; Huang, W. Neuroprotective effect of crude polysaccharide isolated from the fruiting bodies of Morchella importuna against $\mathrm{H}_{2} \mathrm{O}_{2}$-induced PC12 cell cytotoxicity by reducing oxidative stress. Biomed. Pharmacother. 2016. [CrossRef]

43. Nitha, B.; De, S.; Adhikari, S.K.; Devasagayam, T.P.A.; Janardhanan, K.K. Evaluation of free radical scavenging activity of morel mushroom, Morchella esculenta mycelia: A potential source of therapeutically useful antioxidants. Pharm. Biol. 2010. [CrossRef] [PubMed]

44. Fu, L.; Wang, Y.; Wang, J.; Yang, Y.; Hao, L. Evaluation of the antioxidant activity of extracellular polysaccharides from Morchella esculenta. Food Funct. 2013, 4, 871-879. [CrossRef]

45. Meng, F.; Zhou, B.; Lin, R.; Jia, L.; Liu, X.; Deng, P.; Fan, K.; Wang, G.; Wang, L.; Zhang, J. Extraction optimization and in vivo antioxidant activities of exopolysaccharide by Morchella esculenta SO-01. Bioresour. Technol. 2010. [CrossRef] [PubMed]

46. Strelnik, A.D.; Petukhov, A.S.; Zueva, I.V.; Zobov, V.V.; Petrov, K.A.; Nikolsky, E.E.; Balakin, K.V.; Bachurin, S.O.; Shtyrlin, Y.G. Novel potent pyridoxine-based inhibitors of AChE and BChE, structural analogs of pyridostigmine, with improved in vivo safety profile. Bioorg. Med. Chem. Lett. 2016, 26, 4092-4094. [CrossRef] [PubMed]

47. Boyle, J. Lehninger Principles of Biochemistry, 4th ed.; Nelson, D., Cox, M., Eds.; Wh Freeman: New York, NY, USA, 2008. [CrossRef] 